\title{
PSYCHOLOGICAL AND PEDAGOGICAL SUPPORT FOR THE DEVELOPMENT OF CREATIVE POTENTIAL OF TEACHERS OF UKRAINIAN LANGUAGE AND LITERATURE IN THE SYSTEM OF POSTGRADUATE EDUCATION: BENCHMARKS OF EXPERIMENTAL TEACHING
}

\author{
Syvash $S . V$. \\ Ukraine, Zaporizhzhia, Zaporizhzhia National University
}

DOI: https://doi.org/10.31435/rsglobal_wos/31032020/7009

\begin{tabular}{l} 
ARTICLE INFO \\
Received: 24 January 2020 \\
Accepted: 12 March 2020 \\
Published: 31 March 2020 \\
\hline KEYWORDS \\
development of creative potential, \\
postgraduate pedagogical education, \\
teachers of the Ukrainian language \\
and literature, \\
organizational and pedagogical \\
conditions, \\
motivation, \\
creativity, \\
structural and functional model.
\end{tabular}

\section{ARTICLE INFO}

Received: 24 January 2020

Accepted: 12 March 2020

KEYWORDS

development of creative potential, postgraduate pedagogical education, and literature,

organizational and pedagogical

structural and functional model.

\begin{abstract}
The development of teacher's creative potential is a continuous pedagogical process, constant movement and self-development, in which the system of postgraduate pedagogical education plays the most important role.

The article highlights special role that teachers of Ukrainian language and literature play in shaping culture of speech, linguistic flair, and literary tastes of young Ukrainian citizens. The importance of developing creative potential of teachers in the system of postgraduate pedagogical education is revealed. On the basis of the analysis of philosophical, psychological and pedagogical literature, we have determined organizational and pedagogical conditions, suggested an experimental structural and functional model for the development of creative potential of teachers of Ukrainian language and literature in the system of postgraduate pedagogical education. The conclusion is drawn about the integrity, sustainability and dynamics of the experimental model. It is pointed out that the development of spiritual and creative potential, training pedagogical skills require awareness of oneself as a subject of selfdevelopment in the created educational environment, which is oriented on positive emotional background, innovative and traditional methods and forms of work, actualization of self-educational potential and success.
\end{abstract}

Citation: Syvash S. V. (2020) Psychological and Pedagogical Support for the Development of Creative Potential of Teachers of Ukrainian Language and Literature in the System of Postgraduate Education: Benchmarks of Experimental Teaching. International Academy Journal Web of Scholar. 3(45). doi: 10.31435/rsglobal_wos/31032020/7009

Copyright: (C) 2020 Syvash S. V. This is an open-access article distributed under the terms of the Creative Commons Attribution License (CC BY). The use, distribution or reproduction in other forums is permitted, provided the original author(s) or licensor are credited and that the original publication in this journal is cited, in accordance with accepted academic practice. No use, distribution or reproduction is permitted which does not comply with these terms.

Introduction. In the conditions of fundamental changes and transformations of the modern society, teachers act as educators and mentors, who are deeply aware of their professional mission, individuals, whose creative potential is constantly evolving, causing continuous life-long selfdevelopment and self-improvement. A special role is given to the teachers-philologists, because they form the culture of speech of young citizens.

Teachers of language and literature are culture-oriented, they possess a unique personality, perfect knowledge of their subject in combination with the best traditions of national education, characterized by linguistic sense, developed intelligence, speech memory, high creativity.

According to V. V. Klymenko: "national state program determines strategic directions of the development of education and support for constant spiritual self-perfection of personality, formation of its intellectual and cultural potential as higher national values. Reformation of education suggests the 
development of a creative person capable not only of knowledge transference, but also of the creation of international cultural and spiritual models" [3, p. 3].

Postgraduate pedagogical education (PPE) plays an important role in self-development of teachers, as the training process results in an increase of creative potential, activates the impetus for self-improvement.

"That is why the process of teaching pedagogical staff in the system of postgraduate pedagogical education is considered as professional improvement on the basis of stimulating the development of creative potential, personal growth, during which the task related to the personality of the teacher should be solved" [4, p. 32].

Research results. Despite certain research conducted on the issues of the phenomenon under study and broad coverage of theoretical foundations of the development of individual's creative potential in academic literature, there are still no systematic studies of the development of the creative potential of teachers of Ukrainian language and literature in postgraduate education, since education in modern conditions requires updating of the content and teaching methods.

Significant contribution to the development of theoretical foundations and conceptual provisions on the organization and development of the system of postgraduate pedagogical education was made by such scholars as V. I. Bondar, I. P. Zhernosek, M. Yu. Krasovytskyi, V. I. Maslov, V. V. Oliinyk, N. G. Protasova, T. I. Sushchenko; theoretical principles of educational process in educational establishments were studied by A. M. Alekseiuk, V. I. Bondar, Yu. V. Vasyliev, S. Honcharenko, M. S. Kahan, V. M. Madzihon, V. O. Yakunin; personality-activity and personalitydevelopmental approaches in the process of training, andragogical approach are covered in the works of M. Nowles, P. Jarvis, R. Smith, which allows to determine the specific features of adult learning and ways to improve organization.

Such scholars as N. Y. Voloshina, V. A. Kan-Kalyk, V. I. Khazan, O. M. Kutsevol, T. V. Nikishyna, B. I. Stepanyshyn emphasize inseparability of pedagogical creativity and competence of teachers of Ukrainian language and literature in postgraduate pedagogical activity.

In the research and scholarly works of such psychologists and educators as V. A. Andreiev, O. V. Brushlynskyi, L. S. Vygotskyi, I. I. Drach, V. I. Zagviazynskyi, I. A. Zaziun, V. A. Kan-Kalyk, V. V. Kraievsky, N. V. Kuzmina, O. M. Matiushkin, K. K. Platonov, Ya. O. Ponomariov, S. O. Sysoieva, creativity is considered as a way of becoming a professional educator.

Analysis of psychological and pedagogical literature gives grounds to define the concept of "creative potential" as a complex system of psychogenetic and psychological qualities, integrity of natural and social human potential, a set of abilities, opportunities and properties for the implementation of creative activity, production of creative strategies and tactics in the process, which allow you to find a unique, fundamentally new solution to problems, as well as to provide subjective need of an individual in creative self-realization and self-development.

Training in the system of PPE, aims at the development of creative potential of individuals, and has the following peculiarities: synthesis of theoretical and practical training in modeling pedagogical situation, mastering innovative technologies and methods, self-analysis and selfcontrol, personal programming of self-development. An important task of the pedagogical competence development of Ukrainian language and literature teachers in the system of PPE is the desire to raise themselves to the level of professional standards, formation of professional attitude and acmeological culture.

That is why we consider the construct of "creativity of Ukrainian language and literature teachers in the system of postgraduate pedagogical education" as an integrative system of organized education, aimed at regular, qualitative changes, where a teacher is able to develop competencies in postgraduate environment, choose an individual path in training, realize potential creative opportunities and, as a result, produce an original output of creative activity.

Successful development of the creative potential of teachers in PPE is possible due, first of all, to organizational and pedagogical conditions that ensure close interaction of all components of professional growth. Based on the analysis of reference and psychological-pedagogical literature, we determine that pedagogical conditions are a set of objective and subjective factors that provide the appropriate level of personality development and contribute to efficiency and effectiveness of pedagogical process, professional personal growth. 
Analysis of psychological and pedagogical literature allows to prove the importance of organizational and pedagogical environment as a set of possibilities of content, forms and methods of pedagogical process; as conditions of interaction of organizational forms and pedagogical support, subjects of educational process $[1 ; 5 ; 6 ; 7]$.

With the aim of forming the phenomenon under study, as a result of the analysis of the reference, psychological and pedagogical literature and practical experience of the author, we can assume that willingness of philological teachers to develop creative potential in the system of professional training is made possible provided the development and implementation of complex organizational and pedagogical, would contribute to the formation of positive motivational values, self-development and self-actualization, the creation of spiritual-creative interaction in the procedural aspect, improving teacher's professional skills.

Thus, we have identified the following organizational and pedagogical conditions that provide the appropriate level of development and contribute to improving the efficiency and effectiveness of pedagogical process, professional personal growth, namely: activation of motivational settings in the process of developing the creative potential of teachers of the Ukrainian language by cultivating subjectivity; creative environment as a condition for activating communicative potential of a teacher's personality through professional and creative subject interaction of participants of the educational process; providing prevention of the professional burnout syndrome of teachers of Ukrainian language and literature in the system of PPE in order to improve successful professional and creative activity; stimulation of professional and creative selfrealization of teachers of Ukrainian language and literature in the system of postgraduate pedagogical education by means of reflective projection.

For a deeper disclosure of the concept of the phenomenon under study, we transform organizational and pedagogical conditions of the development of creative potential of Ukrainian teachers in PPE system into a structural and functional model that aims to perform certain functions, which lead to a specific result - a high level of creative potential of teachers in the system of postgraduate pedagogical education.

Structural-functional model of the development of the creative potential of teachersphilologists in the system of PPE reflects the unity of target- organizational (scientific approaches, principles, structure of creative potential of teachers of the Ukrainian language and literature in the system of PPE, including motivational, cognitive, procedural-activity and reflexive components), substantive-procedural (organizational and pedagogical conditions, content, forms and methods of the development of creative potential of Ukrainian teachers in the system of PPE), diagnostic (criteria, indices, level of creative potential of teachers of Ukrainian language and literature in the system of postgraduate education) and productive that displays the final result.

Conclusions. Therefore, the core requirement to modern education is to be student-oriented, to treat individuals as its basic value. That's why in the process of education, forms, methods and technologies are not the major target, they create favorable conditions for self-development of individuals. In the context of our research they are seen as essential for self-development of teachers of Ukrainian language and literature in the system postgraduate pedagogical education.

Thus, the following considerations allow us to summarize the following ideas: on the basis of the analysis of psychological and pedagogical literature, we have identified organizational and pedagogical conditions for the development of creative potential of teachers of Ukrainian language and literature in the system of postgraduate pedagogical education, determined the structure of the development of creative potential of teachers-philologists, created structural-functional model of this phenomenon. The structure of the created model is based on the principles of logical development of the phenomenon under study: from the initial state of creative potential of Ukrainian teachers to purposeful and gradual growth in the system of PPE. In addition, cultivation of spiritual and creative potential, training pedagogical skills require self-awareness as a subject of selfdevelopment in the created educational environment, oriented on positive emotional background, innovative and traditional methods and forms of work, actualization of self-educational potential and success. 


\section{REFERENCES}

1. Haleieva A. P. (2009). Orhanizatsiyno-pedahohichni umovy vykhovnoyi diyal'nosti u vyshchomu ahrarnomu navchal'nomu zakladi : avtoref. dys. ...kand. ped. nauk: 13.00.07 [Organizational and Pedagogical Conditions of Educational Activity in Higher Agrarian Institution: extended abstract of dissertation. Candidate of Pedagogical Sciences: 13.00.07]. Drohobych. 22. [in Ukrainian].

2. Honcharenko S. (1997) Ukrainskyi pedahohichnyi slovnyk [Ukrainian pedagogical dictionary]. Kyiv: Lybid. 376. [in Ukrainian].

3. Klymenko V. V. (2006) Psykholohiya tvorchosti. Navchal'nyy posibnyk [Psychology of Creativity. Tutorial]. Kyiv: Center for Educational Literature. 408. [in Ukrainian].

4. Maslai H. (2008) Rozvytok tvorchoho potentsialu vchytelya [Development of Teacher's Creative Potential]. Postgraduate Education in Ukraine. 1, 32-35[in Ukrainian].

5. Pavlov S. N. (1999). Organizatsionno-pedagogicheskiye usloviya formirovaniya obshchestvennogo mneniya organami mestnogo samoupravleniya : avtoref. diss. ... kand. ped. nauk: 13.00.01 [Organizational and Pedagogical Conditions for the Formation of Public Opinion by Local Authorities: extended abstract of dissertation. Candidate of Pedagogical Sciences: 13.00.01]. Magnitogorsk. 23. [in Ukrainian].

6. Babanskiy YU. K. (1988) Pedagogika [ Pedagogy / ed. Yu. K. Babansky]. Moscow: Pedagogy. 432. [in Russian].

7. Romenets V. A. (2001) Psykholohiia tvorchosti [Psychology of creativity: textbook. manual]: navch. posibnyk. 2-he vyd., dop. Kyiv: Lybid. 288. [in Ukrainian]. 